Tropical Journal of Pharmaceutical Research November 2016; 15 (11): 2459-2465

ISSN: $1596-5996$ (print); 1596-9827 (electronic)

(C) Pharmacotherapy Group, Faculty of Pharmacy, University of Benin, Benin City, 300001 Nigeria.

All rights reserved.

Available online at http://www.tjpr.org

Original Research Article

http://dx.doi.org/10.4314/tjpr.v15i11.22

\title{
Determination of secondary metabolites and antioxidant activity of some boraginaceae species growing in Iran
}

\author{
Amir Gharib ${ }^{1 *}$ and Masoud Godarzee ${ }^{2}$ \\ ${ }^{1}$ Department of Laboratory Sciences, Borujerd Branch, Islamic Azad University, Borujerd, Iran, ${ }^{2}$ Department of Biology, \\ Borujerd Branch, Islamic Azad University, Borujerd, Iran \\ *For correspondence: Email: amirgharib@gmail.com; Tel: +986623500201; Fax: +986624453013
}

Received: 31 May 2016

Revised accepted: 18 October 2016

\begin{abstract}
Purpose: To evaluate the antioxidant potential, flavonoids, and total phenols as well as cyanidin 3glucoside and delphinidin 3-glucoside contents of some Boraginaceae species that grow in Iran.

Methods: The aqueous and ethanol extracts of the plants were prepared. The free radical scavenging activity of the extracts was determined using 2,2-diphenyl-1-picrylhydrazyl (DPPH) radical method. Total phenolic and flavonoid contents of the extracts were assessed by Folin-Ciocalteu and aluminium chloride colorimetric assays, respectively. Furthermore, cyanidin 3-glucoside and delphinidin 3glucoside contents of the extracts were determined using high-performance liquid chromatography (HPLC) method.

Results: The most powerful free radical scavenging activity with $50 \%$ inhibitory concentration $\left(I C_{50}\right)$ of $23.13 \pm 1.90 \mu \mathrm{g} \mathrm{mL}^{-1}$ was exerted by the ethanol extract of Nonea caspica, while the weakest IC $C_{50}$ of $364.38 \pm 14.18 \mu \mathrm{g} \mathrm{mL}^{-1}$ was shown by the aqueous extract of Onosma sericeum. Total phenolic content varied among the plants, ranging from $270.33 \pm 2.60$ to $3.40 \pm 0.28 \mathrm{mg} \mathrm{GAE} \mathrm{g}^{-1}$ dry weight. The ethanol extracts of Nonea caspica and Anchusa arvensis displayed the highest total flavonoid content (252.60 \pm 1.80 and $29.13 \pm 1.05 \mathrm{mg} \mathrm{QE} \mathrm{g}^{-1}$ dry weight, respectively). The highest contents of cyanidin and delphinidin 3-glucosides were found in the ethanol extracts of Nonea caspica and Anchusa arvensis, respectively.

Conclusion: The results show that some of the plants have potent antioxidant activities which may justify the ethno-therapeutic usage of these plants by traditional healers.
\end{abstract}

Keywords: Boraginaceae, Polyphenol, Antioxidant activity, Cyanidin 3-glucoside, Delphinidin 3glucoside, Nonea caspica, Onosma sericeum, Anchusa arvensis

Tropical Journal of Pharmaceutical Research is indexed by Science Citation Index (SciSearch), Scopus, International Pharmaceutical Abstract, Chemical Abstracts, Embase, Index Copernicus, EBSCO, African Index Medicus, JournalSeek, Journal Citation Reports/Science Edition, Directory of Open Access Journals (DOAJ), African Journal Online, Bioline International, Open-J-Gate and Pharmacy Abstracts

\section{INTRODUCTION}

The Boraginaceae family includes a variety of herbs, shrubs, and trees totaling about 146 genera and 2000 species found in the worldwide [1]. The main secondary metabolites of these plants are alkaloids, flavonoids, polyphenols, phytosterols and terpenoids, that some of them showed antioxidant and antibiotic activities [2]. Some Boraginaceae species were used for burns and wounds healing in folk medicine around the world [3]. Wound healing property of this family is related to their antibacterial, antiviral, antioxidant and anti-inflammatory activities, which is directly dependent on their phenolic compounds, such as flavonoids and phenolic acids [2]. As a result, a direct relationship between antioxidant activities and phenolic contents of extracts from Boraginaceae species has been established [4]. Many reported biological effects such as 
antioxidant, anti-inflammatory, antimutagenic and anticancer activities have been attributed to the presence of phenolic and flavonoid compounds, which are widespread in this plant family [5].

Several species of the Boraginaceae family are grown in Iran and some of them, such as borage (Borago officinalis L.) for its antispasmodic, antihypertensive, antipyretic, aphrodisiac and diuretic properties is used widely in Iran's folk medicine [6]. Moreover, it has been reported that borage was useful to treat bronchitis, diarrhea, cramps, kidney ailments and asthma [7].

It has also been observed that some species of Boraginaceae contain shikonin were used for the treatment of hemorrhoids [8]. Furthermore, the findings showed that the various parts of Echium species (Boraginaceae) could be used for their antibacterial, anti-inflammatory, anti-proliferative, antidepressant, antioxidant, antiviral, anxiolytic and cytotoxic properties. [9]. Cyanidin and delphinidin 3-glucosides (Figure $1 \mathrm{~A}$ and $\mathrm{B}$ ) are potent antioxidants and radical-scavengers belong to polyphenols, which found in some fruits and Boraginaceae species, and their levels could affect the antioxidant capacity of some medicinal plants [10]. There are no studies regarding antioxidant potential, flavonoids, and total phenols as well as cyanidin 3-glucoside and delphinidin 3-glucoside contents of some Boraginaceae species that grows in Iran. In the present research, we collected eight species of Boraginaceae family, including Lappula barbata, Onosma bulbotrichum, Rochelia persica, Nonea caspica, Anchusa arvensis, Onosma microcarpum, Onosma sericeum and Trichodesma incanum that according to our knowledge, there were no prior reports on the chemical properties of these plants, and therefore, the main aim of this study was to evaluate the polyphenol content and antioxidant activities of these selected species.

\section{EXPERIMENTAL}

\section{Materials}

Butylated hydroxyanisole (BHA), Folin-Ciocalteu, methanol, sodium acetate, aluminium chloride and ethanol were purchased from Merck (Darmstadt, Germany). Gallic acid, quercetin (QE), delphinidin 3-glucoside, cyanidin 3glucoside, 2, DPPH, formic acid and acetonitrile were obtained Sigma (St. Louis, USA).

\section{Plant materials}

The eight species of Boraginaceae family, including Lappula barbata, Onosma bulbotrichum, Rochelia persica, Nonea caspica, Anchusa arvensis, Onosma microcarpum, Onosma sericeum and Trichodesma incanum were collected during the spring from different regions of Broujerd, Lorestan Province, Iran. These regions have a mild climate with a mean temperature between $20-26{ }^{\circ} \mathrm{C}$ in the spring. The plant samples were identified by Dr. Masoud Godarzee and confirmed by comparison with voucher specimens deposited in the Herbarium of Department of Biology, Faculty of Basic Sciences, Borujerd Branch, Islamic Azad University, Borujerd, Ira The voucher numbers of plants were shown in Table 1.

\section{Preparation of the extracts and fractions}

The aqueous and ethanol extracts of plants were prepared according to the previously reported method [11]. Briefly, the air-dried plants were ground into powder using grinder (Moulinex, France). Subsequently, sample powders (1 g) were blended with $60 \mathrm{~mL}$ of water or $45 \%$ ethanol solvents and were mixed on a sample stirrer at $900 \mathrm{rpm}$ for $1 \mathrm{~min}$, and then the liquid volumes were increased to $100 \mathrm{~mL}$ with used solvents.<smiles>OCC1OC2OC(Oc3cc4c(O)cc(O)cc4[o+]c3-c3ccc(O)c(O)c3)C(O)C1OC2O</smiles>

A<smiles></smiles>

B

Figure 1: Cyanidin 3-glucoside (A) and delphinidin 3-glucoside (B) structures 
These mixtures were placed in a bath by stirring at the required temperature and time and cooled in a refrigerator at $5{ }^{\circ} \mathrm{C}$ and then centrifuged (Shimadzu, Japan) at $2500 \mathrm{rpm}$ for $10 \mathrm{~min}$. Subsequently, the mixtures were vacuum filtered, and the loss solvents were replaced. The extracts were stored at $-20{ }^{\circ} \mathrm{C}$ until used for analysis.

\section{Determination of antioxidant activity}

The free radical scavenging activity was determined using a previously described method with some modifications [12]. Briefly, DPPH solution $(0.2 \mathrm{mM})$ in methanol was prepared. The test samples were dissolved in methanol at different concentrations and $1.5 \mathrm{~mL}$ of these solutions were added to the equal volume of $\mathrm{DPPH}$ solution. The mixtures were shaken vigorously and maintained in the dark for $30 \mathrm{~min}$. Subsequently, the absorbance was measured at $517 \mathrm{~nm}$. The BHA was used as a standard reference. Antioxidant activity (D) was determined as in Eq 1.

$D(\%)=\{(A c-A s) / A c\} 100$

where Ac and As are the absorbance of blank and test samples, respectively.

$\mathrm{IC}_{50}$, which is the concentration required to obtain a $50 \%$ antioxidant capacity, was determined from a graph of antioxidant activity (\%) against extract concentration ( $\mu \mathrm{g} / \mathrm{mL})$.

\section{Total phenolic contents}

The total phenolic content of the samples was determined by the Folin-Ciocalteu method [13]. Briefly, $500 \mu \mathrm{L}$ of different concentrations of extracts were mixed with $2.5 \mathrm{~mL}$ of FolinCiocalteu reagent $(0.2 \mathrm{~N})$. After $5 \mathrm{~min}, 2 \mathrm{~mL}$ of $\mathrm{Na}_{2} \mathrm{CO}_{3}$ solution $(75 \mathrm{~g} / \mathrm{L})$ was added to each solution. Then, all tested solutions were incubated for $120 \mathrm{~min}$ at dark. Subsequently, their optical densities were measured at $760 \mathrm{~nm}$. The total phenolic content of each sample was determined on the basis of the calibration curve of gallic acid and was expressed as gallic acid equivalents (GAE), in milligram per gram of plant sample.

\section{Total flavonoid}

The total flavonoid contents were determined by described method using quercetin as a reference compound [14]. Briefly, $0.5 \mathrm{~mL}$ of each extract $(1: 10 \mathrm{~g} / \mathrm{mL})$ was mixed with $1.5 \mathrm{~mL}$ of methanol, $0.1 \mathrm{~mL}$ of aluminium chloride (10\%), $0.1 \mathrm{~mL}$ of sodium acetate $(1 \mathrm{M})$ and $2.8 \mathrm{~mL}$ of distilled water. Thereafter, solutions were incubated for $30 \mathrm{~min}$ at room temperature and their absorbance was determined at $415 \mathrm{~nm}$. Subsequently, the total phenolic content of the samples was calculated on the basis of the calibration curve of quercetin and was expressed in terms of quercetin equivalent ( $\mathrm{mg}$ of $\mathrm{QE} / \mathrm{g}$ of extract).

\section{HPLC analysis}

The cyanidin and delphinidin 3-glucosides were determined using HPLC method as described previously, with modification [15]. In brief, $10 \mu \mathrm{L}$ of samples was injected into the HPLC column (C18, $4.6 \times 250 \mathrm{~mm}, 5 \mu \mathrm{m}$, Waters, MA, USA). The diode array UV detector and the mobile phases, including (A) $4.5 \%$ aqueous formic acid and (B) $80 \%$ acetonitrile in solution $A$ were used. The elution programs were: 0 - $15 \%$ B (1 min), 15 - $45 \%$ B (12 min), 45 - $100 \%$ B (1 min), 100 $0 \% \mathrm{~B}(1 \mathrm{~min})$, and $0 \% \mathrm{~B}(1 \mathrm{~min})$. The flow rate was $1 \mathrm{~mL} / \mathrm{min}$ and the operation was done in 37 ${ }^{\circ} \mathrm{C}$.

\section{Statistical analysis}

All experiments were done in triplicate and the data are expressed as mean \pm standard deviation (SD). Statistical analysis was performed by one-way analysis of variance of (ANOVA) and $p<0.05$ was considered as statistically significant. Data were analyzed using SPSS analytical software version 19.0 (SPSS Inc., IL, USA).

\section{RESULTS}

The DPPH free radical scavenging activities of the extracts from different plants have been shown in Table 1. Under identical conditions, the radical scavenging activity of the ethanol extracts was higher than that of the aqueous extracts $(p<$ $0.01)$. The most powerful free radical scavenging activity $\left(\mathrm{IC}_{50}=23.13 \pm 1.90 \mu \mathrm{g} / \mathrm{mL}\right)$ was exerted by the ethanol extract of Nonea caspica and the weakest one $\left(\mathrm{IC}_{50}=364.38 \pm 1.18 \mu \mathrm{g} / \mathrm{mL}\right)$ was exhibited by aqueous extract of Onosma sericeum.

As shown in Table 1, the amounts of total phenolic contents were varied widely in the different plants and ranged from $270.33 \pm 2.60$ to $3.4 \pm 0.28 \mathrm{mg} \mathrm{GAE} / \mathrm{g}$ dry weight. Among ethanol extracts, the highest total phenolic content was observed in the Nonea caspica, whereas the lowest content value was found in the Onosma 
sericeum. Under identical conditions, it has been shown that the total phenolic contents for ethanol extracts were higher than those of aqueous extracts $(p<0.01)$.

The data in Table 1 indicated that the amounts of total flavonoid contents were varied widely in the different extracts. The ethanol extracts of Nonea caspica and Anchusa arvensis exhibited the highest total flavonoid contents $(252.60 \pm 1.80$ and $29.13 \pm 1.05 \mathrm{mg} \mathrm{QE} / \mathrm{g}$ dry weight), respectively, while the lowest levels were found in aqueous extracts of Onosma sericeum and Rochelia persica $(2.50 \pm 0.37$ and $9.10 \pm 0.37$ $\mathrm{mg} \mathrm{QE} / \mathrm{g}$ dry weight), respectively. Moreover, under identical conditions, the total flavonoid contents in ethanol extracts were higher than those of aqueous extracts $(p<0.01)$.
The cyanidin 3-glucoside, and delphinidin 3glucoside compositions of the tested plants were shown in Table 2 . The total contents of the delphinidin and cyanidin 3-glucosides were varied from 0 to $215.93 \pm 0.15$ and 0 to $95.23 \pm$ $0.48 \mathrm{mg} \mathrm{kg}^{-1}$ dry weight, respectively. The cyanidin and delphinidin 3-glucosides in the ethanol extracts were higher than those of aqueous extracts under similar conditions $(p<$ 0.05). Likewise, our results revealed that delphinidin and cyanidin 3-glucosides have not been found in the Onosma bulbotrichum and Onosma sericum plants.

The HPLC chromatograms of ethanol extracts of Nonea caspica and Anchusa arvensis were shown in Figures $2 A$ and $B$, respectively.

Table 1: Antioxidant activity, total phenolic and flavonoid contents of ethanol and aqueous extracts of eight species of Boraginaceae family $\left({ }^{*} p<0.05\right.$ and $\left.{ }^{* *} p<0.01\right)$

\begin{tabular}{|c|c|c|c|c|c|c|}
\hline \multirow{2}{*}{$\begin{array}{r}\text { Plant } \\
\text { (Voucher } \\
\text { no.) }\end{array}$} & \multicolumn{2}{|c|}{$\begin{array}{l}\text { Antioxidant activity } \\
\left(\mathrm{IC}_{50}, \mu \mathrm{g} \mathrm{\textrm {mL } ^ { - 1 } )}\right.\end{array}$} & \multicolumn{2}{|c|}{$\begin{array}{l}\text { Total phenolic content } \\
\text { (mg GAE g }{ }^{-1} \text { dry weight) }\end{array}$} & \multicolumn{2}{|c|}{$\begin{array}{l}\text { Total flavonoid content } \\
\text { (mg QE g }{ }^{-1} \text { dry weight) }\end{array}$} \\
\hline & $\begin{array}{l}\text { Aqueous } \\
\text { Extract }\end{array}$ & $\begin{array}{l}\text { Ethanol } \\
\text { Extract }\end{array}$ & $\begin{array}{l}\text { Aqueous } \\
\text { Extract }\end{array}$ & $\begin{array}{l}\text { Ethanol } \\
\text { Extract }\end{array}$ & $\begin{array}{l}\text { Aqueous } \\
\text { Extract }\end{array}$ & $\begin{array}{l}\text { Ethanol } \\
\text { Extract }\end{array}$ \\
\hline $\begin{array}{l}\text { Lappula } \\
\text { barbata (178) }\end{array}$ & $221.70 \pm 8.27$ & $209.10 \pm 1.56$ & $20.10 \pm 0.85$ & $25.11 \pm 0.13$ & $17.10 \pm 0.56$ & $20.01 \pm 0.35$ \\
\hline $\begin{array}{l}\text { Onosma } \\
\text { bulbotrichum } \\
\text { (163) }\end{array}$ & $295.50 \pm 3.50$ & $281.50 \pm 1.62$ & $11.50 \pm 0.62$ & $18.30 \pm 0.50$ & $11.50 \pm 0.85$ & $13.30 \pm 0.54$ \\
\hline $\begin{array}{l}\text { Rochelia } \\
\text { persica (173) }\end{array}$ & $345.12 \pm 1.73$ & $315.11 \pm 2.86$ & $13.10 \pm 0.86$ & $16.08 \pm 1.30$ & $9.10 \pm 0.37$ & $12.58 \pm 0.90$ \\
\hline $\begin{array}{l}\text { Nonea } \\
\text { caspica (132) }\end{array}$ & $42.18 \pm 1.41^{* *}$ & $\underset{*}{23.13 \pm 1.90 *}$ & $\underset{* *}{148.13 \pm 1.90}$ & $\underset{* *}{270.33 \pm 2.60}$ & $\underset{* *}{121.17 \pm 3.80}$ & $\underset{*}{252.60 \pm 1.80^{*}}$ \\
\hline $\begin{array}{l}\text { Anchusa } \\
\text { arvensis (194) }\end{array}$ & $164.36 \pm 2.80$ & $141.15 \pm 2.60$ & $28.15 \pm 2.40$ & $35.54 \pm 0.57$ & $21.74 \pm 1.80$ & $29.13 \pm 1.05$ \\
\hline $\begin{array}{l}\text { Onosma } \\
\text { microcarpum } \\
\text { (165) }\end{array}$ & $301.27 \pm 1.35$ & $278.20 \pm 3.50$ & $15.20 \pm 1.30$ & $19.30 \pm 1.50$ & $11.20 \pm 0.35$ & $14.50 \pm 0.85$ \\
\hline $\begin{array}{l}\text { Onosma } \\
\text { sericeum } \\
(168)\end{array}$ & $\begin{array}{c}364.38 \pm 1.18 \\
*\end{array}$ & $\begin{array}{c}346.50 \pm 2.74 \\
*\end{array}$ & $3.40 \pm 0.28^{*}$ & $5.60 \pm 0.41^{*}$ & $2.50 \pm 0.37^{*}$ & $4.20 \pm 0.12^{*}$ \\
\hline $\begin{array}{l}\text { Trichodesma } \\
\text { incanum } \\
\text { (151) }\end{array}$ & $250.19 \pm 3.65$ & $221.18 \pm 4.46$ & $22.18 \pm 0.47$ & $25.45 \pm 0.31$ & $17.28 \pm 0.65$ & $21.18 \pm 0.90$ \\
\hline
\end{tabular}

Table 2: Cyanidin 3-glucoside and delphinidin 3-glucoside contents of ethanol and aqueous extracts of eight species of Boraginaceae family $\left({ }^{*} p<0.05\right.$ and $\left.{ }^{* *} p<0.01\right)$

\begin{tabular}{|c|c|c|c|c|}
\hline \multirow[t]{2}{*}{ Plant } & \multicolumn{2}{|c|}{$\begin{array}{c}\text { Cyanidin 3-glucoside content } \\
\text { ( } \mu \mathrm{g} \mathrm{mg}^{-1} \text { dry weight) }\end{array}$} & \multicolumn{2}{|c|}{$\begin{array}{c}\text { Delphinidin 3-glucoside content } \\
\text { ( } \mu \mathrm{g} \mathrm{mg}^{-1} \text { dry weight) }\end{array}$} \\
\hline & $\begin{array}{l}\text { Aqueous } \\
\text { Extract }\end{array}$ & $\begin{array}{l}\text { Ethanol } \\
\text { Extract }\end{array}$ & $\begin{array}{l}\text { Aqueous } \\
\text { Extract }\end{array}$ & $\begin{array}{l}\text { Ethanol } \\
\text { Extract }\end{array}$ \\
\hline Lappula barbata & $15.15 \pm 0.21$ & $18.26 \pm 0.44$ & $21.15 \pm 0.50$ & $26.59 \pm 0.81$ \\
\hline Onosma bulbotrichum & $\mathrm{Nil}^{* *}$ & $\mathrm{Nil}^{* *}$ & $\mathrm{Nil}^{* *}$ & $\mathrm{Nil}^{* *}$ \\
\hline Rochelia persica & $30.89 \pm 0.11$ & $36.18 \pm 0.91$ & $35.18 \pm 0.69$ & $42.25 \pm 0.10$ \\
\hline Nonea cospica & $83.25 \pm 0.93^{*}$ & $95.23 \pm 0.48^{*}$ & $191.83 \pm 0.67^{*}$ & $215.93 \pm 0.15^{*}$ \\
\hline Anchusa arvensis & $70.14 \pm 0.50$ & $73.15 \pm 0.98$ & $71.23 \pm 0.22$ & $79.69 \pm 0.13$ \\
\hline Onosma microcarpum & $59.13 \pm 0.20$ & $66.10 \pm 0.87$ & $58.14 \pm 0.26$ & $65.42 \pm 0.74$ \\
\hline Onosma sericeum & $\mathrm{Nil}^{* *}$ & $\mathrm{Nil}^{* *}$ & $\mathrm{Nil}^{* *}$ & $\mathrm{Nil}^{* *}$ \\
\hline Trichodesma incanum & $34.15 \pm 0.45$ & $45.28 \pm 0.52$ & $43.29 \pm 0.91$ & $50.16 \pm 0.46$ \\
\hline
\end{tabular}


A
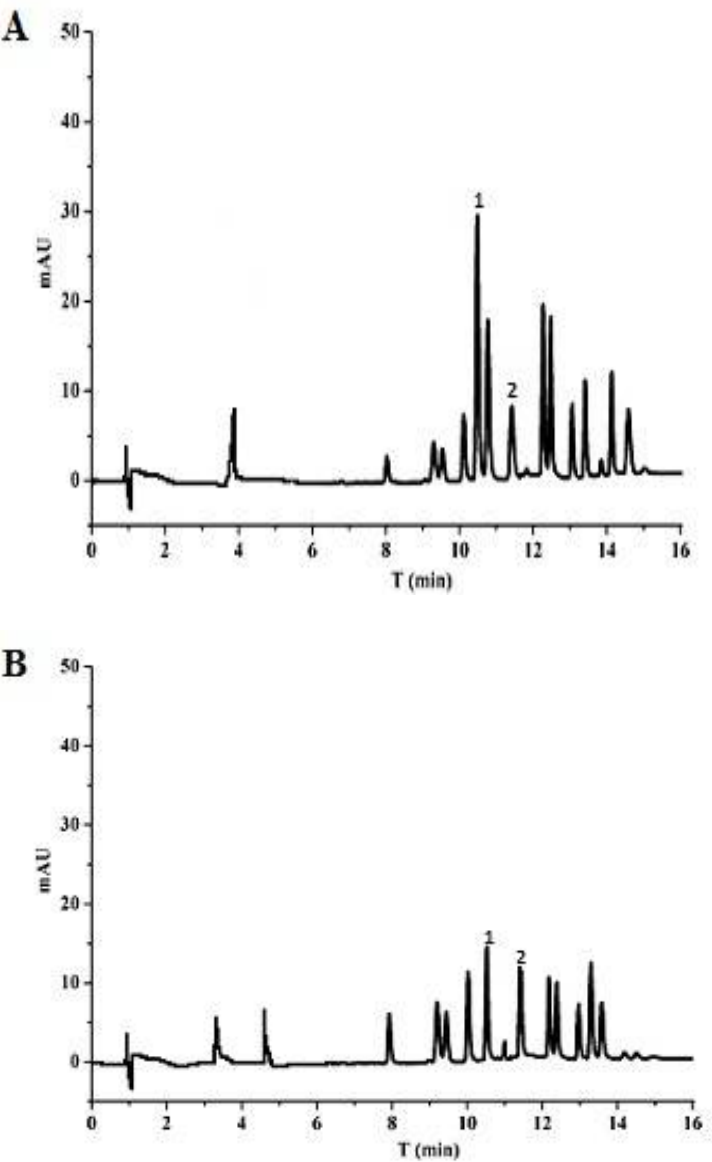

Figure 2: HPLC chromatograms of ethanol extracts of Nonea caspica (A) and Anchusa arvensis (B); 1: Delphinidin 3-glucoside and 2: Cyanidin 3-glucoside

\section{DISCUSSION}

Since ancient times, medicinal plants were used in folk medicine, and for many years these plants have been particularly investigated for their total phenol and flavonoid contents and their antioxidant effects [16]. In global folk medicine, some Boraginaceae species have been used for the treatment and prevention of many ailments and diseases and have shown a tremendous resource for the development of new drugs [2,3]. The sufficient evidence of the therapeutic efficacy of these medicinal plants is manifested in their antioxidant activities that related to their effective materials especially phenolic compounds [4]. Many species of the Boraginaceae family are grown in Iran and some of them are used in ethno-medicine [6].

However, there were no or insufficient studies about their secondary metabolites and antioxidant properties, and therefore in the present study, we evaluated the antioxidant activities, total phenol and flavonoid contents of eight species of this family. Flavonoids and other phenolic compounds are commonly found in plants, and many of these effective components have several biological activities including antioxidative, anti-diabetic, anti-carcinogenic, antimicrobial, anti-allergic, anti-mutagenic and anti-inflammatory properties. [5]. Many studies focused on the biological properties of phenolic compounds, which have potent free radical scavenging and antioxidant activities [17]. It has been reported that the total phenolic content in extracts could be related to the solvent polarity [18]. Moreover, compared to mono-component solvents, the alcohol/water solutions showed better influence on the extractability of phenolic compounds [19]. In agreement with these findings, our data showed that the use of $45 \%$ ethanol-water solvent compared to distilled water could increase the extraction yield of total phenolic compounds. The antioxidant activities of flavonoids and other phenolic compounds are based on their abilities to donate hydrogen atoms to free radicals and chelating transition metals. [15]. Our results showed a positive correlation between antioxidant activities and the total phenolic and flavonoid contents of extracts. These data were in agreement with the earlier studies about the variety of species belonging to the Boraginaceae family, including Borago officinalis L., Onosma dichroanthum Boiss., Cordia multispicata, Ehretia laevis, Cordia myxa, Tournefortia bicolor and Lithospermum erythrorhizon, which in these plants a significant positive correlation between total phenolic content and antioxidant activity was observed [20].

Cyanidin and delphinidin 3-glucosides belong to the group of anthocyanins and polyphenol compounds and are considered for the biological properties consist of potent radical-scavenging and antioxidant effects which may protect cells from oxidative damage and reduce the risk of cancer and cardiovascular diseases and as well as inhibit the development of diabetes mellitus [21]. The cyanidin and delphinidin 3-glucosides found in some fruits such as apples and plums, and in some species of Boraginaceae [22]. It has been reported that dried petals of Echium amoenum have phenolic compounds like rosmarinic acid, cyanidin and delphinidin 3glucosides [23]. Moreover, the previous research showed that the rate of delphinidin 3-glucoside in the flower of Borago officinalis L. was significant [24]. The cyanidin 3-glucoside and delphinidin 3glucoside contents of eight tested plants were determined for the first time by the HPLC method. The high concentrations of cyanidin and delphinidin 3-glucosides were found in the ethanol extracts of Nonea caspica and Anchusa 
arvensis, respectively. This result may explain their higher antioxidant activities compared to other tested plants because it has been reported that procyanidins such as cyanidin and delphinidin 3-glucosides have the strongest radical-scavenging power among all natural phenolic compounds [25].

\section{CONCLUSION}

The results of this study show that some species of Boraginaceae family are rich in phenolic constituents and possess antioxidant activity. Thus, these plants, which are rich in phenolic acids and flavonoids, can be considered as good sources of natural antioxidants. Their potent antioxidant activity may justify their use in traditional herbal medicine in Iran. However, more studies are required to fully ascertain the therapeutic potentials of these plants.

\section{DECLARATIONS}

\section{Acknowledgement}

This study was supported by Islamic Azad University, Borujerd Branch, Iran. The authors would like to acknowledge the staff of the university.

\section{Conflict of Interest}

No conflict of interest associated with this work.

\section{Contribution of Authors}

The authors declare that this work was done by the authors named in this article and all liabilities pertaining to claims relating to the content of this article will be borne by them.

\section{Open Access}

This is an Open Access article distributed under the terms of the Creative Commons Attribution License, which permits unrestricted use, distribution, and reproduction in any medium, provided the original work is properly credited.

\section{REFERENCES}

1. Ahmed HO, Kordofani MA. Leaf and stem anatomy of five species from the genus Heliotropium L. (Boraginaceae) in Sudan. J Chem Pharm Res 2012; 4: 4575-4581.

2. Sousa $C$, Moita $E$, Valentão $P$, Fernandes $F$, Monteiro $P$, Andrade $P B$. Effects of colored and non-colored phenolics of Echium plantagineum $L$. bee pollen in Caco-2 cells under oxidative stress induced by tert-butyl hydroperoxide. J Agric Food Chem 2015; 63: 20832091.

3. Alias/ J, Barikbin B, Khoshzaban F, Naseri M, Sedaghat $R$, Kamalinejad M, Talei D, Emadi F, Akbari Z, Aliasl F, Jalaly NY, Mohseni-Moghaddam P. Effect of Arnebia euchroma ointment on post-laser wound healing in rats. J Cosmet Laser Ther 2015; 17: 41-45.

4. Ahmad S, Ahmad S, Bibi A, Ishaq MS, Afridi MS, Kanwal $F$, Zakir M, Fatima F. Phytochemical analysis, antioxidant activity, fatty acids composition, and functional group analysis of Heliotropium bacciferum. Sci World J 2014; 2014: 829076-829084.

5. Salem N, Msaada K, Hammami M, Jday A, Salem S, Limam F, Marzouk B. Variations in Tunisian borage essential oil profiles and their antioxidant activities during flowering. Nat Prod Res 2014; 28: 1919-1922.

6. Ghahremanitamadon $F$, Shahidi S, Zargooshnia $S$, Nikkhah A, Ranjbar A, Soleimani Asl S. Protective effects of Borago officinalis extract on amyloid $\beta$-peptide (25-35)-induced memory impairment in male rats: a behavioral study. Biomed Res Int 2014; 2014: 798535798535.

7. Arm JP, Boyce JA, Wang L, Chhay H, Zahid M, Patil V, Govindarajulu $U$, Ivester $P$, Weaver $K L$, Sergeant $S$, et al. Impact of botanical oils on polyunsaturated fatty acid metabolism and leukotriene generation in mild asthmatics. Lipids Health Dis 2013; 12: 141-152.

8. Tosun A, Akkol EK, Bahadir O, Yeşilada E. Evaluation of anti-inflammatory and antinociceptive activities of some Onosma L. species growing in Turkey. J Ethnopharmacol 2008; 120: 378-381.

9. Sayyah M, Sayyah M, Kamalinejad M. A preliminary randomized double blind clinical trial on the efficacy of aqueous extract of Echium amoenum in the treatment of mild to moderate major depression. Prog Neuropsychopharmacol Biol Psychiatry 2006; 30: 166169.

10. Simirgiotis MJ, Quispe C, Areche C, Sepúlveda $B$. Phenolic compounds in Chilean mistletoe (Quintral, Tristerix tetrandus) Analyzed by UHPLCQ/Orbitrap/MS/MS and its antioxidant properties. Molecules 2016; 21: 245-259.

11. Segovia F, Lupo B, Peiró S, Gordon MH, Almajano MP. Extraction of antioxidants from Borage (Borago officinalis L.) leaves-optimization by response surface method and application in oil-in-water emulsions. Antioxidants 2014; 3: 339-357.

12. Hatami T, Emami SA, Miraghaee SS, Mojarrab M. Total phenolic contents and antioxidant activities of different extracts and fractions from the aerial parts of Artemisia biennis Willd. Iran J Pharm Res 2014; 13: 551-559.

13. Lee JH, Renita M, Fioritto RJ, Martin SST, Schwartz SJ, Vodovotz $Y$. Isoflavone characterization and antioxidant activity of Ohio soybeans. J Agr Food Chem 2004; 52: 2647-2651.

14. Chang CC, Yang MH, Wen HM, Chern JC. Estimation of total flavonoid content in propolis by two complementary

Trop J Pharm Res, November 2016; 15(11): 2464 
colorimetric methods. J Food Drug Anal 2002; 10: 178182.

15. Lopes-Lutz D, Dettmann J, Nimalaratne C, Schieber A. Characterization and quantification of polyphenols in Amazon grape (Pourouma cecropiifolia Martius). Molecules 2010; 15: 8543-8552.

16. Ernst E. The efficacy of herbal medicine-an overview. Fund Clin Pharm 2005; 19: 405-409.

17. Ivanova $D$, Gerova $D$, Chervenkov $T$, Yankova $T$. Polyphenols and antioxidant capacity of Bulgarian medicinal plants. J Ethnopharmacol 2005; 96: 145-150.

18. Fatima H, Khan K, Zia M, Ur-Rehman T, Mirza B, Haq IU. Extraction optimization of medicinally important metabolites from Datura innoxia Mill.: an in vitro biological and phytochemical investigation. BMC Complement Altern Med 2015; 15: 376-393.

19. Antioxidant and proliferative effects of aqueous and ethanolic extracts of Symphytum officinale on 3T3 Swiss albino mouse fibroblast cell line. Asian J Plant Sci Res 2014; 4: 62-68.

20. Cai $Y$, Luo Q, Sun $M$, Corke $H$. Antioxidant activity and phenolic compounds of 112 traditional Chinese medicinal plants associated with anticancer. Life Sci 2004; 74: 2157-2184.
21. Gharib A, Faezizadeh Z, Godarzee M. Treatment of diabetes in the mouse model by delphinidin and cyanidin hydrochloride in free and liposomal forms. Planta Med 2013; 79: 1599-1604.

22. Mehrabani M, Ghassemi N, Sajjadi E, Ghannadi A, Shams-Ardakani M. Main phenolic compound of petals of Echium amoenum Fisch. and C.A. Mey., A famous medicinal plant of Iran. Daru J Pharm Sci 2005; 13: 6569.

23. Abed A, Vaseghi G, Jafari E, Fattahian E, Babhadiashar $N$, Abed M. Echium Amoenum Fisch \& Mey.: A review on its pharmacological and medicinal properties. Asian $\mathrm{J}$ Med Pharm Res. 2014; 4: 21-23.

24. Salem N, Msaada K, Hammami M, Limam F, Vasapollo $G$, Marzouk B. Variation in anthocyanin and essential oil composition and their antioxidant potentialities during flower development of Borage (Borago officinalis L.). Plant Biosys 2014; 148: 444-459.

25. Ayranci E, Erkan N. Radical scavenging capacity of methanolic Phillyrea latifolia L. extract: anthocyanin and phenolic acids composition of fruits. Molecules 2013; 18: 1798-1810. 